\title{
The Practices and Functions of Customer Reference Marketing - Leveraging Customer References as Marketing Assets
}

\author{
Anne Jalkala \\ Researcher, Department of Industrial Management, Faculty of Technology Management \\ Lappeenranta University of Technology \\ P.O. Box 20, 53851 Lappeenranta, Finland \\ Tel: + 358 - 5 - 6212623 \\ E-mail: anne.jalkala@lut.fi \\ Risto T. Salminen \\ Professor, Department of Industrial Management, Faculty of Technology Management \\ Lappeenranta University of Technology \\ P.O. Box 20, 53851 Lappeenranta, Finland \\ Tel: + $358-5-6212645$ \\ E-mail: risto.salminen@lut.fi
}

Keywords: Customer references, Customer relationships, Marketing assets, Industrial marketing, Resourcebased view

\begin{abstract}
:
This multiple-case study focuses on the practices and functions of customer reference marketing, and on the ways through which customer references can be deployed as marketing assets. The research is based on multiple-case-study methodology and the empirical findings were derived from an in-depth analysis of 38 semi-structured personal interviews with managers in four case companies operating in the fields of process and information technology. The findings show that industrial suppliers are able to leverage their customer references as marketing assets externally through various practices in order to (1) gain status-transfer effects from reputable customers, (2) signal passing a selection process and achieving an enhanced market position, (3) concretize and demonstrate complex solutions, and (4) provide indirect evidence of their experience, previous performance, technological functionality, and delivered customer value. Customer references can also be leveraged internally to (1) facilitate organizational learning, (2) advance offering development, (3) motivate personnel through internally shared success stories, and (4) develop understanding of customer needs, internal competencies, and delivered customer value. By identifying the practices and functions related to customer reference marketing the paper deepens understanding of this highly relevant but relatively underresearched industrial marketing phenomenon and contributes to the literature on customer-based marketing assets.
\end{abstract}

\section{Introduction}

The philosophy of harnessing loyal customers as part of the sales and marketing team has increasingly become a driver of many industrial firms' marketing and sales efforts. Due to the perceived high risk faced by potential buyers, companies selling complex solutions to industrial buyers and governmental institutions need to increase their credibility through customer references (e.g., Windahl et al., 2004; Salminen and Möller, 2006; Veres, 2009). Customer references have long played an important role in the area of process technology in the form of reference visits to existing customers' sites and reference lists accompanying the offer. Nowadays the practices related to customer reference marketing are more diverse as many suppliers use the Internet as a communication channel. Industrial technology and service providers such as ABB and Eaton are publishing numerous client case studies and customer success stories on their Web sites. Moreover, managers in the information technology and communications industry have realized that testimonials and demonstrations from existing customers can be used as convincing and cost-effective marketing instruments. Consequently, customer reference marketing has become an increasingly relevant part of the marketing strategy among companies operating in business-to-business technology. Large IT firms such as Microsoft, Dell, IBM, SAP, and Sun Microsystems have coordinated customer reference programs designed to encourage their business customers to participate in various reference activities ranging from being 
interviewed for a customer case or video testimonial to hosting a reference visit or talking at an industry event. For example, SAP, an enterprise software provider, recruits its customers for its reference activities by offering them visibility and an opportunity to be highlighted as a 'Best-Run Business'.

Concepts such as "customer advocacy marketing", "customer evidence marketing", "customer testimonial marketing" and "customer reference marketing" often overlap and are used among b-to-b marketing practitioners to refer to the phenomenon of leveraging existing customers and the value delivered to them in the company's marketing activities. Given the overall focus of industrial marketing research on buyer behavior and customer orientation, it is surprising that customer reference marketing, one of the most customer-driven phenomena in b-to-b marketing, has received relatively little academic attention. Studies focusing on customer references have been conducted mainly in the context of small high-technology companies, and have emphasized the importance of references in terms of credibility generation and visibility (Elfring and Hulsink, 2003; Lechner and Dowling, 2003; Gomez-arias and Montermoso, 2007). There are studies on certain practices related to customer reference marketing, such as the use of references on company Web sites (Jalkala and Salminen, forthcoming) and the success factors of a reference visit (Salminen, 2001). Recognizing the gap in the academic research on customer references Salminen and Möller (2006) conducted an extensive literature review covering marketing textbooks and academic publications, and proposed a conceptual framework including the referencing process and the antecedent factors influencing the need for their use. Our study extends their work through an empirical analysis of the different practices and related underlying functions of customer reference marketing.

Although the importance of customer references for b-to-b firms has been acknowledged in the research (Helm, 2000; Salminen and Möller, 2006; Gomez-arias and Montermoso, 2007; Ojasalo et al., 2008), it seems that academic knowledge lags behind industry practice, and we need more understanding about the various practices and functions related to this kind of marketing. It remains unclear what the underlying functions of the different practices are, and how companies are actually leveraging customer references as marketing assets. In order to enhance understanding of this increasingly relevant industrial marketing phenomenon, we need to empirically examine the variety of practices through which companies execute customer reference marketing, and to explore the different ways in which the references can be leveraged as marketing assets. We address this gap through the following three research questions: 1) What are the practices that companies use in customer reference marketing? 2) What are the functions of customer reference marketing? 3) How can customer references be leveraged as marketing assets?

We address these questions through a multiple case study concerning the practices and functions of customer reference marketing, and the ways in which references can be leveraged as marketing assets. Our study advances the emerging theory related to customer references (Salminen and Möller, 2006) by shedding light on the underlying mechanisms of the phenomenon. It also contributes to the resource-based view of the firm (e.g., Penrose, 1959; Wernerfelt, 1984; Grant, 1991), and particularly to the customer-based view of strategy and firm growth (Zander and Zander, 2005), in terms of addressing the multifaceted nature of customer references as marketing assets for companies operating in industrial markets. The customer-based view of strategy and firm growth stresses the high relevance of existing customer relationships and accumulated experience to firm performance (Zander and Zander, 2005). We propose that focusing on customer references as marketing assets may bring out some overlooked factors explaining the role that existing customer relationships and delivered solutions play in the quest for growth and competitive advantage among industrial suppliers. Through the identification of different ways in which customer references can be leveraged as marketing assets the study provides new insights into customer-based marketing assets (e.g. Srivastava et al., 1998; Hooley et al., 1998; Hooley et al., 2005).

The article is structured as follows. First, the nature of customer reference marketing and the role of customer references as marketing assets are explained in the context of previous research on customer references, the resource-based view (RBV) and the literature on marketing assets. Secondly, the selected methodology and the process of data gathering and analysis are described. Thirdly, the empirical findings from the four case companies are discussed with reference to illustrative extracts from the data. Finally, conclusions are drawn and managerial as well as theoretical implications are suggested. 


\section{The nature of customer reference marketing}

Customer reference marketing could be considered one way of leveraging and capturing benefits from customer relationships (Sawhney and Zabin, 2002) by using customer relationships and delivered customer solutions in the company's marketing efforts. The practices of customer reference marketing could be categorized as external and internal (Salminen and Möller, 2006). In the former case the supplier signals references to potential buyers and other stakeholders. In the latter, the supplier uses customer reference internally though various practices, such as internal success stories and the use of a customer-reference database to gain internal outcomes, such as sales force training and better targeting of bidding efforts (Salminen and Möller, 2006).

Prior research on customer references has identified two different levels, the relationship level and the delivery level (Salminen, 1999). Firstly, industrial suppliers use their relationship with the reference customer as a marketing tool through displaying the name of the customer on the company Web site, for example. Thus, on the relationship level it is a question of the benefits the supplier gains from being associated with the reference customer. Relationships with large and prestigious customers may have particularly high reference value to an industrial supplier (Walter et al., 2001). Secondly, throughout the existence of a customer relationship there may be several solutions referring to individual projects or deliveries that could be used as 'reference solutions', 'reference projects' or 'reference deliveries'. The importance of these value-creation activities in terms of customer reference marketing is evident in official procurement procedures in which the supplier's past performance is evaluated through "the list of works carried out", "previous projects" or "delivered customer solutions", for example (Salminen, 1999). Incorporating both of these levels, we define the concept of customer reference as a customer relationship and the related value-creation activities that a firm leverages externally or internally in its marketing efforts.

In analyzing the phenomenon of customer reference marketing we need to be aware that customers may contribute to the supplier's market access either actively (by giving referrals and providing connections to other network actors) or passively (through their reputation or image of being associated with the supplier) (Helfert and Vith, 1999). For example, a reference list including large and prestigious customers may have a valuable reference effect, even though the customers do not actively promote the supplier. Furthermore, a track record of reputable customers in the form of reference lists may provide substantial value through status transfer. Relationships with prestigious reference customers are status-enhancing: they can improve the reputation of the supplier through status-transfer mechanisms. The effects of having reputable reference customers could thus be traced back to social-exchange theory, according to which actors' reputations are constructed in part from the identities of their associates (Blau, 1964). According to network theorists, relationships implicitly transfer status between the parties involved (Stuart et al., 1999).

Stuart et al. (1999) describe three possible social mechanisms that may explain the status-transfer process. Firstly, relationships have reciprocal influences on the reputations of actors. Accordingly, the reference customer's reputation may be damaged if the supplier is of very low quality. Given this possibility, the highstatus customer has a strong incentive to avoid low-quality exchange partners, and to be exclusive in its customer selection, which in turn positively affects the potential customer's perception of the quality of the supplier. Secondly, the evaluative capabilities of well-known organizations are perceived to be strong, and there is a presumption that prestigious organizations evaluate their suppliers thoroughly. Because prominent organizations are viewed as experts in the due diligence process the fact that one of them has selected a particular supplier is a valuable signal to other customers. Thirdly, relationships with prominent organizations signal reliability. These mechanisms may partly explain the advantage that (especially young) companies gain from having and leveraging prestigious customers as references. Recognized exchange partners are especially important to young companies because they signal the endorsement of a reputable, credible organization (Podolny, 1993; Stuart et al., 1999), and help in terms of overcoming the liability of newness (Stinchcombe, 1965; Lechner and Dowling, 2003). Following Podolny's (1993) suggestion we propose that customer reference marketing sends a positive status-enhancing signal when the supplier is associated having a relationship with a reputable customer. Thus, a reference list containing high-status customers sends a signal to the market and to other firms that the supplier is a viable partner because it has the trust of the industry leaders.

Certain forms of customer reference marketing, such as reference calls, site visits, and user meetings, involve personal interaction and word-of-mouth between customers, and can thus be only partially managed. 
Originally stemming from the consumer-marketing context, word-of-mouth behavior has also been studied to some extent in the context of industrial markets (e.g., Webster, 1970; Martilla, 1971; Money et al., 1998; Money, 2004; Hansen et al., 2008). However, as the concept by definition refers to informal information exchange between individuals (Westbrook, 1987), it does not provide tools to explain all the aspects of supplier-initiated customer reference marketing, because it does not include the supplier's own influence on the process or the status transfer effects of a strong reference-customer portfolio described above. However, word-of-mouth does have an important function as it is considered a credible source of communication (Reichheld and Sasser, 1990), and several practices of customer reference marketing, such as reference visits (Salminen, 2001), encourage positive word-of-mouth behavior.

\section{Customer references as marketing assets}

According to the resource-based view (RBV) a company's resources are the basis for building competitive advantage (Penrose, 1959; Wernerfelt, 1984; Grant, 1991). Competitive advantage is gained either by having more resources than the competitors and/or utilizing them better (Barney, 1991). From the resource-based perspective customer references could be considered part of the firm's customer-based assets (Hooley et al., 1998), which are accumulated through the relationships the firm has built with its customers and are often regarded as the most important type of marketing assets (Hooley et al., 1998). Other customer-based assets include brand names, customer loyalty and current market position (Hooley et al., 1998). The recognition of customer relationships and customer-based assets as key determinants of a firm's future success is widely discussed in the growing body of literature on marketing resources and assets (e.g., Srivastava et al., 1998; Hooley et al., 1998; Hooley et al., 1999; Hooley et al., 2005; Lacey and Morgan, 2009).

The market value of firms lies increasingly in their intangible assets (Lusch and Harvey, 1994) and intangible marketing assets, such as brand equity (e.g. Aaker, 1991; Walley et al., 2007) and customer equity (e.g. Blattberg and Deighton, 1996; Rust et al., 2000), have attracted considerable attention in the literature. Despite the growing body of research on intangible marketing assets, the processes through which firms obtain, develop, and leverage customer relationships as assets to create and maintain competitive advantage are not well understood (Sirmon et al., 2007). Thus, in the resource based view there is a need to pay more attention to the role and importance of customer relationships, and to examine them as a source of competitive advantage and firm growth (Zander and Zander, 2005). Moreover, further empirical effort to identify key marketing assets and capabilities in specific business contexts is needed (Hooley et al., 1998). Given these gaps in knowledge we contend that focusing on the different ways in which customer references can be leveraged as marketing assets offers an interesting perspective on how the firm's set of delivered customer solutions and existing customer relationships can be leveraged as marketing asset to build competitive advantage and growth in the context of industrial markets.

Customer references as assets are closely related to other intangible assets in that they help in building the industrial brand (Blombäck and Axelsson, 2007) and the firm's reputation and credibility (Salminen and Möller, 2006). The existing portfolio of customer references is also a strong indicator of the supplier's market position. Just as other marketing actions both create and leverage market-based assets (Rust et al., 2004), customer reference marketing may help in developing new customer relationships and thus in building other marketing assets such as market position and customer equity.

It has been noted in previous research that the industry context and the business environment may determine the importance of various marketing assets (Hooley et al., 2005). According to Stuart et al. (1999), the regard paid to the "connected" actor, such as a reference customer, and its endeavors is enhanced in markets characterized by uncertainty. Further, when the perceived risk is high, potential customers and other stakeholders such as investors make quality judgments through careful consideration of the previous accomplishments of the organization (Stuart et al., 1999). Given these findings we propose that the relevance of customer references is reinforced in market conditions characterized by uncertainty and high perceived risk, and thus customer references are important customer-based marketing assets for an industrial suppliers operating in these kinds of markets. 


\section{Methodology}

The multiple-case study (e.g., Yin, 1984; Eisenhardt, 1989; Eisenhardt and Graebner, 2007) was selected as the main research method for several reasons. First of all, given that academic empirical research on customer reference marketing is at a relatively early stage, case study will help in identifying multiple aspects of the phenomenon. Secondly, as the purpose of the research is to identify and analyze the underlying mechanisms of customer reference marketing, case-study methodology provides the tools for in-depth consideration and characterization of the phenomenon. Thirdly, the case method is especially applicable in addressing 'how' and 'why' questions (Yin, 1984), and is thus relevant in terms of finding an answer to the third research question concerning how customer references can be leveraged as marketing assets. The selected multiple case study methodology enabled us to gain a holistic perspective on each case company's customer reference practices and thus capture all of the potentially rich and meaningful characteristics of the phenomenon. Four cases are analyzed in order to highlight the different aspects of customer reference marketing.

\subsection{The case companies}

The selection of the unit of analysis is critical in theory-building case studies (Yin, 1984; Eisenhardt, 1989). In the present study, the selected unit of analysis is a company. The following criteria were used in selecting the four case companies in accordance with the aim of the study to identify the practices and functions of customer reference marketing: 1) industry type, 2) company size, and 3) growth targets. Firstly, all the companies operate in industrial markets in which the monetary value of transactions is high and the complexity of the offerings further increases buyers' perceived risk. Case companies A and B operate in process technology, in which customer references have long played an important role (Salminen, 2006). Case companies $\mathrm{C}$ and $\mathrm{D}$, on the other hand, operate in the information technology industry, in which customer reference marketing is an important part of the marketing and sales operations as companies providing information technology solutions tend to have advanced practices (Arnold, 2003). Secondly, relatively large companies were selected in order to cover a variety of practices, as small companies tend to have a limited set of practices available. Thirdly, all the case companies invest in the development of new products and offerings, and have high growth targets and thus a specific need to use references in new technology and market areas. Table 1 gives details of the selected cases.

Table 1. Characteristics of the case companies

\begin{tabular}{|c|c|c|c|c|}
\hline Case details & Company A & Company B & Company $\mathrm{C}$ & Company D \\
\hline $\begin{array}{l}\text { Main type of } \\
\text { business }\end{array}$ & $\begin{array}{l}\text { Equipment } \\
\text { manufacturer }\end{array}$ & $\begin{array}{l}\text { Project business } \\
\text { company }\end{array}$ & Solution provider & Solution provider \\
\hline Industry & Filtration equipment & Process technology & IT solutions & $\begin{array}{l}\text { Telecommunicatio } \\
\text { ns infrastructure }\end{array}$ \\
\hline $\begin{array}{l}\text { Sales }(1000 \\
\text { EUR) }\end{array}$ & 200000 & 1200000 & 1800000 & 15000000 \\
\hline Employees & 600 & 2500 & 16000 & 60000 \\
\hline $\begin{array}{l}\text { Primary } \\
\text { customers }\end{array}$ & $\begin{array}{l}\text { Chemical process } \\
\text { industry, } \\
\text { Mining and metal } \\
\text { industry }\end{array}$ & $\begin{array}{l}\text { Mining and metal } \\
\text { industry }\end{array}$ & $\begin{array}{l}\text { Banking and } \\
\text { insurance industry, } \\
\text { Telecom and media } \\
\text { industry, Forest and } \\
\text { energy industry }\end{array}$ & $\begin{array}{l}\text { Telecommunicatio } \\
\text { n operators }\end{array}$ \\
\hline
\end{tabular}

Case company A supplies solid/liquid separation equipment and related services to the mining and metals, and the chemical process industry. It also offers a comprehensive range of services, including technical support, modernization and upgrading services, as well as a spare and wear parts service. Case company $B$ provides process technologies for the mining and metals industries worldwide. The technologies offered cover the whole chain of processing ores into pure metals, and the solutions range from single equipment deliveries to manufacturing lines and entire turnkey process plants. Case company $C$ produces different kinds of information-technology solutions to corporations and governmental institutions. The offerings of the company include consulting, developing and hosting services for its customers' digital businesses. Case company $D$ operates globally through five business units and offers services and solutions for the design, deployment, maintenance and management of telecommunication networks. 


\subsection{Data collection and analysis}

The data was primarily collected through personal interviews with representatives of the four case companies. An interview schema was used, designed to identify the practices and functions of customer reference marketing, and to capture the various ways in which the case companies deployed their customer references as marketing assets. The interviews were semi-structured, and involved open-ended questions regarding the company's external and internal customer reference marketing practices and functions. The respondents were involved in related tasks in sales, marketing, customer relationship management, service, business development, and corporate strategy. The primary data for the study consists of 38 personal interviews in four case companies. The data obtained through the personal interviews was supplemented with an analysis of secondary data including internal and external documents such as process descriptions, annual reports, and marketing material. Each interview was tape-recorded, transcribed and coded with the help of NVivo software, a program designed for qualitative data analysis.

Nvivo software was used to code the interview data in the first phase of the analysis. The open coding was used in order to identify the different customer reference marketing practices employed in the case companies. Information obtained from the interviews concerning the external customer reference practices was confirmed by going through the company Web sites and company specific marketing materials. In the second phase of analysis the data was analyzed with a view to forming an initial categorization of the different underlying functions of customer reference marketing. This categorization was further analyzed in order to explore the different aspects and mechanisms of external and internal practices. As the analysis progressed this categorization was further developed, the focus being on the ways in which the case companies leveraged their customer references as marketing assets. In order to demonstrate the consistency of the findings and the reasoning through which the data was interpreted, the findings are reported together with illustrative, representative quotations from the interview respondents.

\section{Findings}

In the following we describe the identified practices and functions of customer reference marketing deployed by the case companies, and give an analysis of the role of customer references as marketing assets. All the case companies deployed several external and internal practices. Those identified are summarized in Table 2 for each case company. 
Table 2. Identified customer reference marketing practices

\begin{tabular}{|c|c|c|c|c|}
\hline & Case company A & Case company B & Case company $\mathbf{C}$ & Case Company D \\
\hline \multicolumn{5}{|c|}{ IDENTIFIED CUSTOMER REFERENCE MARKETING PRACTICES } \\
\hline External & $\begin{array}{l}\text { - Customer reference } \\
\text { lists } \\
\text { - Reference visits } \\
\text { - Reference calls } \\
\text { - Press releases } \\
\text { about closed deals } \\
\text { - Case studies } \\
\text { (detailed } \\
\text { descriptions of } \\
\text { customer cases) } \\
\text { - "Service stories" } \\
\text { on the company } \\
\text { Web site }\end{array}$ & $\begin{array}{l}\text { - Customer reference } \\
\text { lists } \\
\text { - Reference visits } \\
\text { - Reference calls } \\
\text { - Press releases } \\
\text { about closed deals } \\
\text { - "Success stories" } \\
\text { on the Web site } \\
\text { - Customer } \\
\text { interviews and } \\
\text { "success stories" in } \\
\text { the customer } \\
\text { magazine }\end{array}$ & $\begin{array}{l}\text { - Customer reference } \\
\text { lists } \\
\text { - Reference visits } \\
\text { (occasionally) } \\
\text { - Reference calls } \\
\text { - Press releases about } \\
\text { closed deals } \\
\text { - "Top stories" and } \\
\text { "Customer cases" on } \\
\text { the company Web } \\
\text { site }\end{array}$ & $\begin{array}{l}\text { - Customer reference } \\
\text { lists } \\
\text { - Reference visits } \\
\text { (occasionally) } \\
\text { - Reference calls } \\
\text { - Press releases about } \\
\text { closed deals } \\
\text { - "Customer success } \\
\text { stories" on the } \\
\text { company Web Site } \\
\text { - "White label stories" } \\
\text { (case descriptions } \\
\text { without the } \\
\text { customer's name) } \\
\text { - Customer reference } \\
\text { podcasts } \\
\text { - Success story video } \\
\text { testimonials }\end{array}$ \\
\hline Internal & $\begin{array}{l}\text { - Reference } \\
\text { deliveries as a } \\
\text { schema for } \\
\text { evaluating } \\
\text { equipment capacity } \\
\text { for new projects } \\
\text { - Company-wide } \\
\text { internal customer } \\
\text { reference database } \\
\text { (in the launching } \\
\text { phase) }\end{array}$ & $\begin{array}{l}\text { - Lessons learned - } \\
\text { practices from } \\
\text { reference projects } \\
\text { - Internal reference } \\
\text { documentation } \\
\text { template } \\
\text { - Reference sites as a } \\
\text { venue for } \\
\text { employee training }\end{array}$ & $\begin{array}{l}\text { - Corporate-wide } \\
\text { internal customer } \\
\text { reference database } \\
\text { - Internal "customer } \\
\text { success story" - } \\
\text { communication } \\
\text { procedures } \\
\text { - Finding solutions for } \\
\text { other customer } \\
\text { industries }\end{array}$ & $\begin{array}{l}\text { - "Iconic cases" as a } \\
\text { schema for offering } \\
\text { development } \\
\text { - Value-based } \\
\text { argumentation teams } \\
\text { for measuring the } \\
\text { delivered customer } \\
\text { value } \\
\text { - "Case of the month" } \\
\text { and "Customer } \\
\text { solution of the year" } \\
\text { announcements } \\
\text { - Planned "solution of } \\
\text { the quarter" contest }\end{array}$ \\
\hline
\end{tabular}

\subsection{External customer reference marketing}

Leveraging customer references externally by demonstrating them to potential customers and to other stakeholders was considered an important tool for sales and marketing in all the case companies. As shown in Table 2, they deployed various although rather uniform practices in their external customer reference marketing, ranging from reference lists and success stories to press releases, reference calls and visits to the reference customer's sites. Although they had all adopted rather similar practices for using customer references, the emphasis varied.

Reference lists and reference visits were reported to have a key role in the sales process in both process technology companies (A and B). Salespeople use customer references through different kinds of reference lists accompanied with an offer, and through reference visits to customers' sites. Reference lists seem to have the function of signaling the supplier's track record and experience in a certain market or technology area, as demonstrated in the following statements from a representative of case company A:

"References are an essential part of the sales process as they prove that someone else has bought from us, which helps the sales job...We have reference lists of different filters, and we have also been collecting lists that serve a certain group of customers. You need to show the potential customer a list of references located in the same geographical area where the customer operates, or from the same application area it is interested in, then it works. We also have shorter reference lists covering specific applications that include the customers' names, the type and number of sold filters and the filtering area. This gives us extra back-up that we have experience of different kinds of applications. (Application Development Manager, case company A) 
As the above quotation shows, using customer references as part of the sales process is considered important for reducing the potential buyer's perceived risk by demonstrating previous installations. Reference lists seem to provide indirect evidence about the supplier's experience. The respondents reported that sometimes the customer relationship could be leveraged as a reference even in the early phases of its development. A common practice in all the case companies was to communicate the clinching of a deal with a high-status customer through a press release if at all possible. This type of 'closed deal' reference marketing, which occurs prior to actual delivery, may be used especially when it is a question of acquiring a first reference customer in a new technology or market area. As a representative of case company D, a well-known telecommunications operator, stated:

\begin{abstract}
"Acquiring the first reference for a new technology involves working very closely with the operator. Often it starts as a pilot case, running some tests together, exploring and verifying the solution. In the first case it involves some sort of risk sharing. We go out in public together with a joint press release. Typically it happens at a large Mobile world conference, and then it becomes a big thing that we're in this together. It's extremely important for us to have a prestigious operator partner, who makes a difference." (Head of Marketing Development, case company D)
\end{abstract}

The kind of activity described above sends a signal that the supplier has earned a form of certification by successfully navigating the selection process of a selective and highly capable evaluator. In highly competitive markets the public announcement of a major deal may also serve to signal the supplier's enhanced market position to investors, competitors, and other stakeholders. As part of the post-merger restructuring process, case company $\mathrm{D}$ needed to reposition itself as a market player, and used customer reference data in order to build credibility (both internally and externally) and to obtain evidence by analyzing and signaling the large installed base. A representative of the company described the role of customer reference information in his own work in the following way:

"It's part of our market positioning, actually. We say that these are the customers with whom we have a contract and on-going or conducted equipment deliveries. We also mention that we have 25 non-public customer references. We work with the reference data and try to think how we could position ourselves as the number-one player in this business. For example, we analyze our share of the commercial networks in certain technological areas." (Business Development Manager, case company D)

Customer reference descriptions such as success stories and case reports were considered an important reference marketing practice in all the case companies. However, companies $\mathrm{C}$ and $\mathrm{D}$, which operate in the IT industry, had invested more effort in producing such descriptions and other reference-related marketing material than the process-technology companies. Company D has success-story videos and recorded reference podcasts available on its Web site, and company $C$ has a repository of over 100 written customer cases on its site. The respondents in this company reported that the technological complexity of the solutions further increased the importance of having well documented reference cases. They considered case descriptions the only viable way of demonstrating the complex solutions and their actual business impacts to managers and high-level decision makers within and outside the case company:

\footnotetext{
“When I go to see a customer I don't talk directly about our offering. Instead, I tell them stories through our reference cases. I may have three slides and a picture of our reference on each slide. I tell a story through the reference case, about the business impacts that our solution has had, what we have done there, what our role has been, what the customer was thinking, and what his initial goal was. References are basically the only sales tool that I have." (Director, Strategic Sales, case company C)
}

As demonstrated above, customer case descriptions are instrumental in making abstract and complex offerings more concrete as they provide real-life examples of implemented solutions. Thus, an important function of customer reference marketing practiced through reference descriptions is to demonstrate and concretize the supplier's solution. Reference visits also effectively demonstrate how the technology works in a real-life setting, especially in process technology (case companies A and B). Visits to customers' sites, rather than written reference descriptions, were reported to have an important role in the technology sales process. Representative of the case company A described the role of reference visits in the following way:

"References are a substantial part of our sales process. When we go to a customer's reference site they demonstrate the installed technology to the potential customer, and show their production figures and 
operation costs. In this way we can show potential customers how the technology works, how the personnel have learned to use it, and how certain malfunctions can be fixed." (Regional Director, case company A)

A representative of the case company $\mathrm{B}$ emphasized the role of customer references as a instrumental part of the risk analysis process in customers' investment decision making:

\begin{abstract}
"Our industry is very conservative and the investments and risks related to acquiring new production equipment are high. Operational failures may have severe financial consequences. Firms in this industry have to conduct thorough studies and analyses to satisfy project financiers. In this process references are very important in evaluating the technological risks so that we can show that this same technology has been adopted somewhere else and that it works well." Vice President, Sales and Marketing, case company B)
\end{abstract}

In the above quotations the respondents highlight the importance of providing indirect evidence of the functionality of the technology through customer references and thus reducing the perceived risk of a potential buyer and other stakeholders, such as project financiers. Reference visits were used only occasionally in case companies $\mathrm{C}$ and $\mathrm{D}$, and the emphasis was more on other practices such as inviting customers to talk at industry events. Even though few visits were made, the importance of personal interaction between the reference customer and the potential customer was considered highly valuable. According to the analysis, customer reference marketing has a crucial role not only in demonstrating and concretizing the solution but also in demonstrating its value and the business benefits that the supplier has been able to deliver. The importance of measuring the delivered customer value from reference cases was considered high in all the case companies. However, only company D (telecommunications network equipment provider) had put in concrete efforts to develop practices for estimating the delivered benefits in their value-based argumentation teams, which try to identify value elements through extensive description of customer cases, for example. However, measurement and communication of the delivered customer value were considered challenging as the benefits are often hard to measure and are realized only after the project completion. Reference customers may also be reluctant to share information about received business benefits due to competitive pressures.

\begin{abstract}
"We have these value-based argumentation teams, and our goal is to quantify the benefits that the customer has received, but often, if the customer grants permission to use their name and gives a testimonial, then they don't want to give the exact numbers. We have these white-label stories that give a more detailed picture without mentioning the customer's name. It can be quite sensitive data for them, and therefore they may agree in doing a story with their name, but without the facts about the received business value." (Solution Portfolio Development Manager, case company D)
\end{abstract}

As demonstrated above, customers may not want to act as a reference because of competitive pressures as they would not want to risk revealing information that might benefit their competitors. The willingness to act as a reference depends on how well the customer is treated by frontline employees, which in turn is determined by all the functional areas that contribute to the experience. According to the respondents, positive recognition and visibility are important motivators for acting as a reference customer. Other reasons for participating in reference activities include industry recognition, having access to high-level decision makers, and being given key-customer status. Neither credits nor monetary rewards were used in motivating customers to act as a reference in any of the case companies as this was against their regulations.

When the supplier has high control over the interaction the reference marketing also involves practices other than showing reference lists and communicating success stories, including more informal information transfer among customers. User conferences and customer excellence awards are two examples, the aim being to trigger positive word-of-mouth. A representative of case company D described the role of these practices in the following way:

\footnotetext{
"Customers say good things about us mainly through the events we organize. For example, we have a capital market base event that we organize together with our parent company, and people talk to investors and analysts, and there are many other operators there as well. The main goal there is that the operators will talk about us, say we're a nice company to work with. The benefit to the customer is the prestige and visibility." (Head of Marketing Development, case company D)
} 
The practice described above differs from the use of success stories and reference visits or lists in that they involve more informal information exchange that cannot be totally controlled by the supplier. It seems that the function of these types of practice is to encourage positive word-of-mouth by creating opportunities for customers to discuss their experiences and to learn from their peers.

In sum, the case companies deploy various practices in their external customer reference marketing, which seems to have multiple functions. It serves as a mechanism for gaining status transfer effects, but according to the findings it also serves as a tool for demonstrating and concretizing the supplier's solution. Furthermore, customer references lend credibility as they provide indirect evidence about the supplier's experience, previous performance, technological functionality, and ability to deliver customer value. As the analysis shows, the external customer reference practices deployed by the case companies range from simple marketor industry-area-specific reference lists to recorded video testimonials (case company D) and organized customer events involving personal interaction between customers. Similarly, the contributions of a reference customer vary from giving permission to use the company name and logo to more demanding actions such as being interviewed for a customer case, taking reference calls, hosting reference visits, speaking at events (e.g., giving a presentation at a trade show), and talking to the press. The role thus ranges from allowing the company's name and logo to be used to participating in material production and media activities, and engaging in personal interaction with customers. The supplier's control over customer reference marketing seems to follow a continuum from high to low depending on the reference customer's role. The proposed functions are not tightly connected with certain customer reference practices, but instead tend to accumulate as the reference customer's role increases. (see Table 3). 
Table 3. Identified practices and proposed functions of external customer reference marketing

\begin{tabular}{|c|c|c|c|c|}
\hline $\begin{array}{l}\text { The role of } \\
\text { customer } \\
\text { references as } \\
\text { marketing assets }\end{array}$ & $\begin{array}{l}\text { The proposed function } \\
\text { of reference marketing } \\
\text { activity (external) }\end{array}$ & $\begin{array}{l}\text { The supplier's } \\
\text { reference marketing } \\
\text { practices (external) }\end{array}$ & $\begin{array}{l}\text { The reference } \\
\text { customer's role }\end{array}$ & $\begin{array}{l}\text { The } \\
\text { supplier's } \\
\text { control }\end{array}$ \\
\hline \multirow{4}{*}{$\begin{array}{l}\text { Critical sales and } \\
\text { promotional tool }\end{array}$} & $\begin{array}{l}\text { Provide indirect } \\
\text { evidence about } \\
\text { experience } \\
\text { - Enhance credibility } \\
\text { through status- } \\
\text { transfer effects }\end{array}$ & - Reference lists & $\begin{array}{l}\text { Allowing company } \\
\text { name and logo } \\
\text { usage }\end{array}$ & \multirow[t]{4}{*}{ High } \\
\hline & $\begin{array}{l}\text { - Demonstrate and } \\
\text { concretize the } \\
\text { solution } \\
\text { - Provide indirect } \\
\text { evidence of previous } \\
\text { performance } \\
\text { - Demonstrate the } \\
\text { value of the solution }\end{array}$ & $\begin{array}{l}\text { - Success stories, } \\
\text { Customer cases, Case } \\
\text { studies, ROI-studies } \\
\text { - Sales presentation } \\
\text { reference slides } \\
\text { - Audio/video } \\
\text { testimonial (webcast / } \\
\text { podcast) } \\
\text { - Recorded reference } \\
\text { interviews/ podcasts }\end{array}$ & $\begin{array}{l}\text { Participating in } \\
\text { producing } \\
\text { marketing/sales } \\
\text { material }\end{array}$ & \\
\hline & $\begin{array}{l}\text { - Serve as a certificate } \\
\text { of passing through a } \\
\text { selection process } \\
\text { - Signal an enhanced } \\
\text { market position }\end{array}$ & $\begin{array}{l}\text { - Press releases } \\
\text { - Articles in trade } \\
\text { journals } \\
\text { - Promotional material } \\
\text { - Customer } \\
\text { presentations at } \\
\text { seminars and } \\
\text { conferences }\end{array}$ & $\begin{array}{l}\text { Participating in } \\
\text { media activities }\end{array}$ & \\
\hline & $\begin{array}{l}\text { Provide indirect } \\
\text { evidence about the } \\
\text { functionality of the } \\
\text { technology } \\
\text { - Generate positive } \\
\text { word-of-mouth }\end{array}$ & $\begin{array}{l}\text { - Reference calls (one- } \\
\text { to-one/one-to-many) } \\
\text { - On-site reference } \\
\text { visits } \\
\text { - Customer events and } \\
\text { meetings } \\
\text { - Social media }\end{array}$ & $\begin{array}{l}\text { Participating in } \\
\text { personal } \\
\text { interaction with } \\
\text { potential } \\
\text { customer(s) }\end{array}$ & \\
\hline
\end{tabular}

\subsection{Internal customer reference marketing}

The internal practices for leveraging customer references varied among the case companies and involved many organizational functions including sales, project organization, and research and development. The filtration equipment provider (case company A) used reference information about previous deliveries as a tool when evaluating the equipment capacity required for a potential new customer. Many of the respondents mentioned that the portfolio of customer references served as an important resource pool for learning and training purposes. Reference sites are frequently used in case company B as venues for training new employees. The company delivers complex large-scale technology projects, and 'lessons learned' from reference projects were considered important in terms of the successful delivery and execution of subsequent projects. The sales function used reference documentation occasionally for learning purposes, such as through win-lose analyses, which aim to uncover the reasons why a specific sales case was won or lost. Customer reference descriptions were mentioned as valuable learning material for training new salespeople in all the case companies. Case studies, success stories and other customer-reference-related material seem to 
work as artifacts that codify experience from the reference project into a story format and serve as a means of sharing knowledge across the organization.

Case companies $\mathrm{A}$ and $\mathrm{C}$ had recently launched an internal development project for documenting and gathering customer-reference-related information, and customer cases from every business unit are now documented in an organization-wide reference database. In case company $\mathrm{C}$ the documentation includes information about the customer's problem and needs, the reasons why the company was selected as a supplier, technical information about the solution and its delivery, and information about the business benefits the customer gained from the solution. The company has also established a specific unit for gathering information across different business divisions about the solutions it has delivered related to an offering called 'digital media'. The business development manager of this unit described their role in the following way:

\begin{abstract}
"Our role is to map the know-how that we have around our organization and package it into offerings that our sales organization can market. We communicate internally about the delivered customer cases throughout the organization, and this develops our sales personnel's understanding about our internal capabilities and the solutions they can offer to our customers." (Business Development Manager, case company C)
\end{abstract}

Developing an understanding of customer needs and internal competences by analyzing reference cases was mentioned as being a part of the transformation process from a product orientation towards a solution orientation in case company D. The solution-marketing unit has a systematic process for evaluating each customer case in terms of its external and internal reference value. A representative of the solution portfolio management team described the process in the following way:

"We have an operations model for looking at customer cases internally. We analyze the nature of the case, see if it is conventional or iconic, and whether it differentiates us externally from our competitors. Then we look at the internal factor, does it contain information that is important for learning purposes in terms of customer engagement, ways of working with the customer, or in terms of the solution characteristics?" (Solution Portfolio Development Manager, case company D)

\begin{abstract}
"Using reference cases is not only for marketing and sales. In solution selling it has a connection to R\&D and how well they can use reference information. If the customer challenge is well documented in our reference cases it can help our offering-development people to listen to customer needs more carefully and form a clearer picture of the market situation." (Head of Solution Portfolio Management, case company D)
\end{abstract}

As demonstrated above, apart from its use as a marketing and sales tool, an important reason for gathering reference-related information is to build a resource pool of customer data that facilitates market sensing through the analysis and identification of changing customer needs. On the other hand, case companies $\mathrm{C}$ and $\mathrm{D}$ also strive to use the collected data for creating a more comprehensive and clearer picture of their own internal competences. Customer references are also a valuable, although as yet not fully exploited, resource for building credible value propositions. As a marketing manager in case company $\mathrm{C}$ stated:
"When we make value propositions to our customers and promise, for example, that their customer-service costs will be lower after implementing our solution, our evaluation of the cost reduction is based on calculations from our reference cases. We have measured, analyzed, and calculated the business impacts of our solution from reference cases on existing customers. Unfortunately, we don't have the resources to conduct these analyses systematically enough.” (Marketing Manager, case company C)

Besides contributing to organizational learning and working as an offering-development schema, the internal use of customer references seems to have a role in shaping attitudes and the organizational culture. A delivery project typically involves many technical personnel who are not in direct interaction with the customer. The representatives of case companies $\mathrm{C}$ and $\mathrm{D}$ reported that success stories about recent customer deliveries were important in motivating and bringing the company's technical personnel closer to the customer, helping them to understand the case to which their work had contributed. It is also possible to give recognition to and motivate employees through the internal communication of success stories and "solution of the month" announcements:

"References are important for motivating the personnel. We talk internally about the cases we have worked with in some business unit, and about the new things that we tried. This motivates our people and shows them 
that we can do great stuff. Then there's also the learning function. We tell them how a specific customer case was carried out and what we learned from it." (Key Account Manager, case company C)

In sum, the studied companies leverage customer references internally in various ways, and internal customer reference marketing tends to occur in many forms across different organizational functions as a fragmented and partly unconscious phenomenon rather than as a planned process. The findings suggest that internal customer reference marketing contributes to organizational learning and can be deployed as an instrument for personnel training and motivation building. It can also help in enhancing understanding of customer needs, internal competencies and value delivery through the careful documentation and analysis of customer references. Table 4 depicts the identified practices and proposed functions of internal customer reference marketing.

Table 4. The identified practices and proposed functions of internal customer reference marketing

\begin{tabular}{lll}
$\begin{array}{l}\text { The role of customer } \\
\text { references as marketing } \\
\text { assets }\end{array}$ & $\begin{array}{l}\text { The function of reference-marketing } \\
\text { activity (internal) }\end{array}$ & $\begin{array}{l}\text { The supplier's reference-marketing } \\
\text { practices (internal) }\end{array}$ \\
\hline
\end{tabular}

Template for organizational learning

\section{Knowledge base for customer-need and market sensing, and for understanding internal competences}

\section{Basis for building credible value propositions}

- Enhance organizational experiential learning and reduce redundancy

- Enhance understanding of customer needs and internal competences
- Best-practice and lessons-learned exercises

\section{Schema for offering and new-product development}

\section{Source of internal motivation}

Schema for training and educating personnel
- Develop credible value propositions

- Help in offering development

- Motivate personnel

- Educate and train personnel
- Systematic analysis of a welldocumented portfolio of customer references
- Measuring delivered customer value from reference cases

- Selecting and documenting "iconic cases"

- Internal success stories and "solution of the month" types of announcements

- Internal reference case descriptions and "reference black books"

\subsection{The roles of customer references as marketing assets}

The findings of our study show that customer reference marketing is not merely a tool for, or the responsibility of, marketing and sales. It is a complex cross-departmental set of organizational processes and routines designed to leverage existing and previous customer relationships as marketing assets through various practices. From our observations of the four case companies we could distinguish different ways of leveraging customer reference marketing as an asset. Externally, customer references work as a critical sales and promotional tool through various functions that different external practices fulfill in winning new customers and building the supplier's market credibility. Internally, customer references can act as a marketing asset by providing a template for organizational learning, a knowledge base for customer need and market sensing and understanding of internal competencies, a basis for building credible value propositions, a schema for offering and new product development, a source for internal motivation, and a tool for training and educating personnel. In the following, we will discuss these identified various roles of customer 
references as marketing assets in the light of the customer-based view of strategy and firm growth (Penrose, 1969; Zander and Zander, 2005) and previous research concerning customer references.

Leveraging customer references as $a$ sales and promotional tool has been widely acknowledged in previous research (e.g. Helm, 2000; Salminen and Mölller, 2006; Gomez-Arias and Montermoso, 2007). Our study extends the previous research by suggesting that the functions through which customer references work as a sales and promotional tool are various and not limited to the "referral effect" of customer references emphasized in previous research (e.g. Webster, 1970; Money et al., 1998; Ryals, 2002). The combination of the suggested functions including status transfer effects, solution concretization, and indirect evidence that customer references provide about supplier's experience, previous performance, technological functionality and delivered customer value propose that the underlying mechanisms of customer reference marketing are highly complex and multifaceted. For instance, the value a supplier receives from signaling a recently closed deal with a prestigious customer, such as through press releases, is similar to the benefits that certain types of organizations may receive from the endorsement of licensing agencies (Baum and Oliver, 1991) and from winning certification contests (Rao, 1994).

Leveraging customer references as a template for organizational learning is related to the notion of "economies of repetition" (Davies and Brady, 2000), which firms can achieve by transferring routines and lessons learned from individual projects into a set of organizational tools and a repertoire of stories, and thus conduct the subsequent bids and projects more efficiently and effectively. In line with our findings, Davies and Brady (2000) found in their study on developing organizational capabilities and learning in firms delivering complex product systems that the firms tried to capture the knowledge and experience gained from sales bids and projects and to transfer the lessons learned for re-use in subsequent projects.

Leveraging customer references as a knowledge base for customer-need and market sensing supports the customer-based view of strategy and firm growth (Zander and Zander, 2005) and could be compared with Penrose's (1959) notion of an 'inside track', which refers to the access to information about emerging customer needs that companies can gain through their existing customer relationships, and which could be used to develop new products and offerings. As customer reference marketing requires careful documentation of customer cases and intense interaction with key customer relationships it could help in gaining in-depth insights into the circumstances and particular needs of customers and thus facilitate the pursuit of an inside track. The inside-track and the customer-based view of strategy and firm growth postulate that inside access to information about emerging needs of established customers provides an important basis for sustainable competitive advantage (Penrose, 1959; Zander and Zander, 2005). Our findings contribute to this view by suggesting that the existing customer relationships together with the set of delivered customer solutions form an important basis for an industrial supplier for understanding the emerging customer needs, but also for understanding internal competencies and value delivery abilities.

Leveraging customer references as a as a schema for offering development could also be seen as a pursuit of an 'inside track'. Moreover, this finding can be related to the notion of "economies of recombination" (Grabher, 2004), which result from novel combinations of familiar elements and by-products from previous projects through the reuse of knowledge modules from earlier projects (Grabher, 2004). As our findings demonstrate, customer references may be leveraged to develop offerings and enhance value co-creation with customers through the careful documentation of previous cases and delivered benefits. A key part of this process is to capture and use effectively the existing diverse elements of customer knowledge within the organization, re-organizing knowledge-management systems around customers rather than products (Payne et al., 2008).

Leveraging customer references as a basis for building credible value propositions reflects the importance of understanding and measuring the components of customer value (e.g. Walters, 1999; Anderson et al., 2006, Kothari and Lackner, 2006). The existing pool of customer reference offers a basis for identifying value drivers through careful documentation and measurement of the delivered value from previous customer cases. According to Walters (1999), value-based competitive advantage can be established by identifying and measuring value drivers (Walters, 1999). Successful companies develop a deep understanding of how value gets delivered and quantify the value they provide to their customers (Walters, 1999; Kothari and Lackner, 2006). Leveraging the customer reference portfolio to document and quantify the value received by reference customers could be seen as "outside-in" thinking, which keeps the customer in focus in developing customeraligned value propositions. 
Leveraging customer references internally as a source of internal motivation and as a schema for training and educating personnel relates to the role of stories, which have been found to be effective tools for sharing knowledge, transmitting values and forming a "collective identity" throughout the organization (e.g. Buckler and Zien, 1996; Denning, 2004). Internally communicated customer cases and success stories are basically narratives that link a set of events related to a specific customer solution in some kind of causal sequence. They involve an experience about a certain customer case from the past in which only some individuals were involved, and create a living "collective memory" of the lessons learned, even for newcomers (Buckler and Zien, 1996). Communicating internally about successful customer cases brings recent successes into the present for all members of the enterprise, which helps the personnel to experience their role as key to the successful customer case and may thus inspire the motivation.

As our findings demonstrate, customer references as marketing assets are strongly interlinked with other resources. External use of customer references contributes to building reputation, market credibility and firm's customer equity. Internal use of customer references contributes to organizational learning and personnel's know-how, and an analysis of the existing pool of customer references develops the understanding of internal competencies. Customer references thus incorporate the qualities needed for creating competitive advantage as they take time to develop, involve complex interrelationships with other resources, and cannot be easily transferred to other organizations. We contend that it is absolutely critical for industrial suppliers not to overlook the marketing asset that resides in a firm's customer references. The ongoing trends in global business, such as the increased role of intangible elements in industrial suppliers' offerings and the increased tendency towards value co-creation with customers, seem to further increase the importance of customer references as marketing assets. For instance, evaluating the expected value of the supplier's solution in advance is much more difficult when the value is produced within the relationship in cooperation with the customer (Möller, 2006), and only the existing reference base of similar solutions may provide some estimates of the potential value.

\section{Conclusions}

The purpose of this study was to identify and analyze the various practices and functions of customer reference marketing, and to analyze the ways in which an industrial firm's customer references can be deployed as marketing assets. We defined customer references as intangible customer-based marketing assets consisting of customer relationships and related value-creation activities that the firm leverages externally or internally in its marketing activities. On the basis of previous research and the literature on marketing assets and capabilities, we proposed that customer references are important marketing assets for an industrial supplier operating in business markets characterized by high perceived risk faced by the potential buyer. Our findings from the four cases show that customer reference marketing is a cross-functional phenomenon encompassing several practices and related functions with the purpose to leverage customer references externally and internally. In accordance with our empirical findings we suggested different roles through which customer references could be deployed as marketing assets.

Our first research question aimed to uncover the practices that companies use in customer reference marketing. The analysis of the four case companies identified a repertoire of practices (Table 2) that the case companies employ in external and internal customer reference marketing. The variety of identified customer reference marketing practices may be partly explained by the opportunities that modern information technology provides in managing customer reference data and producing and communicating referencerelated marketing material. Our second research question aimed to uncover the functions of customer reference marketing. Our findings suggest that industrial suppliers use external customer reference marketing practices (1) to gain status-transfer effects from reputable customers, (2) to signal passing a selection process and an enhanced market position, (3) to concretize and demonstrate their solution, and (4) to provide evidence of their experience and previous performance, the technological functionality of the solution, and the delivered customer value. Moreover, industrial suppliers use internal customer reference marketing practices to (1) facilitate organizational learning, (2) to develop their understanding of customer needs, internal competencies and delivered customer value, (3) to advance offering development, and (4) to motivate personnel through internally shared success stories.

Our third research question aimed to identify the ways through which customer references can be leveraged as marketing assets. Findings from the four case companies suggest that customer references can be leveraged 
as (1) a sales and promotional tool, (2) a template for organizational learning, (3) a knowledge base for customer need and market sensing and understanding of internal competencies, (4) a basis for building credible value propositions, (5) a schema for offering and new product development, (6) a source for internal motivation, and as (7) a tool for training and educating personnel.

Previous studies have shown that customer references are essential in new market entry with current products, and play a key role in marketing new, innovative products (Salminen and Möller, 2006). Our results provide empirical evidence that customer reference marketing takes various forms and serves many functions for companies operating in business-to-business markets. We argue that customer reference marketing is critical for an industrial supplier offering complex solutions not only because it serves as a means of increasing market credibility and reducing the potential buyer's risk through several functions, but also because it incorporates several internal functions that contribute to organizational experiential learning and efficiency.

The identified functions of customer reference marketing are partly overlapping. However, their analytical classification and identification increase our understanding of the reasons why industrial firms are practicing it, although their importance and relevance may vary in different organizational contexts. For example, the status-transfer effect gained from having reputable customers is presumably higher for small and newly established firms than for large firms with a well-established reputation. However, the contextual effects that determine the relevance of the different functions of customer reference marketing are beyond the scope of this study.

\section{Theoretical implications}

The results of the study contribute to the emerging theory of customer references (Helm, 2000; Salminen and Möller, 2006) in identifying the different practices and functions of customer reference marketing and thus enhancing understanding of the underlying mechanisms behind this increasingly relevant industrial marketing phenomenon. The findings also contribute to the resource-based view of the firm, and particularly to the literature on marketing assets (Srivastava et al., 1998; Hooley et al., 1998; Hooley et al, 2005; Zander and Zander, 2005), in shedding light on the ways in which customer references can be leveraged externally and internally as customer-based marketing assets in industrial markets. In terms of theory development, we propose that the identified various functions that customer references serve may provide at least partial explanation to the importance of customer-based assets as determinants of firm performance. Thus, the multiple effects of a strong portfolio of customer references on an industrial company's growth and performance should be further addressed in research on customer-based assets.

\section{Managerial implications}

Customer references are marketing assets that can be critical in winning future business and developing the efficiency of company's activities. Companies should therefore treat their portfolio of previous deliveries and customer relationships not just as a source of revenue, but also as a valuable marketing asset that can be leveraged in order to achieve organizational efficiency and organic growth. Marketing practitioners can take the identified repertoire of external and internal practices as a template when planning their customer reference marketing efforts. Given the multiple functions that customer reference marketing fulfills, it must be carefully aligned with the company's strategy and growth objectives. The external customer reference marketing efforts need to be planned together with sales organization in order to build market credibility and support sales in the targeted growth areas. The internal customer reference marketing efforts need to be aligned with corporate-level values to transfer the wanted message and planned together with research and development to support the selected focus areas in offering development.

\section{Limitations and further research}

As our study is limited to an explorative investigation in four case companies in the process and information technology industries, the findings cannot be generalized to other contexts. More academic research is needed in order to enhance understanding of the multifaceted role of this increasingly relevant marketing phenomenon and its functions. Further studies are needed in order to paint a more detailed picture of customer reference marketing practices and functions in other industrial contexts. 


\section{References}

Aaker, D. (1991) Managing Brand Equity, New York: The Free Press.

Anderson, J. C., Narus, J. A. and van Rossum, W. (2006) "Customer value propositions in business markets", Harvard Business Review, Vol 84 No 3, pp. 90-99.

Arnold, C. (2003) "Reference programs keep b-to-b customers satisfied”, Marketing News, Vol 18, pp. 4-5.

Barney, J. (1991) "Firm resources and sustained competitive advantage", Journal of Management, Vol 17 No 1, pp. 99-120.

Baum, J.A.C. and Oliver, C. (1991) "Institutional linkages and organizational mortality", Administrative Science Quarterly, Vol 36 No 2, pp. 187-218.

Blattberg, R.C. and Deighton, J. (1996) "Managing marketing by the customer equity test", Harvard Business Review, Vol 75 No 4, pp. 136-44.

Blau, P. (1964) Exchange and Power in Social Life, John Wiley \& Sons Ltd, New York.

Blombäck, A. and Axelsson, B. (2007) "The role of corporate brand image in the selection of new subcontractors", Journal of Business \& Industrial Marketing, Vol 22 No 6, pp. 418-430.

Buckler, S.A and Zien, K.A. (1996) "The spirituality of innovation: Learning from stories", Journal of Product Innovation Management, Vol 13 No 5, pp. 391-405.

Davies, A., and Brady, T. (2000) "Organizational capabilities and learning in complex product systems: Towards repeatable solutions", Research Policy, Vol 29 No 7/8, pp. 931-953.

Denning, S. (2004) “Telling Tales”, Harvard Business Review, Vol 82 No 5, pp 122-129.

Eisenhardt, K.M. and Graebner, M.E. (2007) "Theory building from cases: opportunities and challenges", Academy of Management Journal, Vol 50 No 1, pp. 25-32.

Eisenhardt, K.M. (1989) "Building theories from case study research", Academy of Management Review, Vol 14 No 4, pp. 532-550.

Elfring, T. and Hulsink, W. (2003) "Networking by entrepreneurs: patterns of tie-formation in emerging organizations", Organization Studies, Vol 28 No 12, pp. 1849-1872.

Gomez-Arias, J.T. and Montermoso, J.P. (2007) "Initial customer reference selection for high technology products", Management Decision, Vol 45 No 6, pp. 982-990.

Grabher, G. (2004) "Temporary architectures of learning: knowledge governance in project ecologies", Organization Studies, Vol 25 No 9, pp. 1491-1514.

Grant, R. M. (1991) "The resource-based theory of competitive advantage: Implications for strategy formulation”, California Management Review, Vol 33 No 3, pp. 114-135.

Hansen, H., Samuelsen, B. M. and Silseth, P. R. (2008) "Customer perceived value in B-t-B service relationships: Investigating the importance of corporate reputation", Industrial Marketing Management, Vol 37 No 2, pp. 206-217. 
Helfert, G. and Vith, K. (1999) "Relationship marketing teams. Improving the utilization of customer relationship potentials through a high team design quality", Industrial Marketing Management, Vol 28 No 5, pp. 553-564.

Helm, Sabrina (2000) Kundempfehlungen als Marketinginstrument, Doctoral Dissertation, University of Düsseldorf.

Hooley, G., Fahy, J., Cox, T., Beracs, J., Fonfara, K. and Snoj, B. (1999) "Marketing capabilities and firm performance: a hierarchical model”, Journal of Market Focused Management, Vol 4 No 3, pp. 259-278.

Hooley, G.J., Greenley, G.E., Cadogan, J.W. and Fahy, J. (2005) "The performance impact of marketing resources", Journal of Business Research, Vol 58 No 1, pp. 18-27.

Hooley, G.J., Möller, K. and Broderick, A.J. (1998) "Competitive positioning and the resource based view of the firm”, Journal of Strategic Marketing, Vol 6 No 2, pp. 97-115.

Jalkala, A. and Salminen, R.T. (2009) "Communicating customer references on industrial companies' Web sites”, Industrial Marketing Management, (In Press).

Kothari, A. and Lackner, J. (2006) "A value based approach to management", Journal of Business \& Industrial Marketing, Vol 21 No 4 pp. 243-249.

Lacey, R. and Morgan, R.M. (2009) "Customer advocacy and the impact of B2B loyalty programs", Journal of Business \& Industrial Marketing, Vol 24 No 1, pp. 3-13.

Lechner, C. and Dowling, M. (2003) "Firm networks: External relationships as sources for the growth and competitiveness of entrepreneurial firms", Entrepreneurship \& Regional Development, Vol 15 No 1, pp. 116.

Lusch, R.F. and Harvey, M.G. (1994) "The case for an off-balance-sheet controller", Sloan Management Review, Vol 35 No 2, pp. 101-106.

Martilla, J. A. (1971) "Word-of-mouth communication in the industrial adoption process", Journal of Marketing Research, Vol 8 No 2, pp. 173-178.

Money, R. B. (2004) "Word-of-mouth promotion and switching behavior in Japanese and American business-to-business service clients", Journal of Business Research, Vol 57 No 3, pp. 297-305.

Money, R. B., Gilly, M. C. and Graham, J. L. (1998) "Explorations of national culture and word-of-mouth referral behavior in the purchase of industrial services in the United States and Japan", Journal of Marketing, Vol 62 No 4, pp. 76-88.

Möller, K. (2006) "Role of competences in creating customer value: A value-creation logic approach", Industrial Marketing Management, Vol 35 No 8, pp. 913-924.

Ojasalo, J., Nätti, S. and Olkkonen, R. (2008) "Brand building in software SMEs: an empirical study", Journal of Product \& Brand Management, Vol 17 No 2, pp. 92-107.

Payne, A., Storbacka, K. and Frow P. (2008) "Managing the co-creation of value", Journal of the Academy of Marketing Science, Vol 36 No 1, pp, 83-96.

Penrose, E. T. (1959) The Theory of the Growth of the Firm, New York: John Wiley \& Sons Inc.

Podolny, J. (1993) “A status-based model of market competition”, American Journal of Sociology, Vol 98 No 4, pp. 829-872. 
Rao, H. (1994) "The social construction of reputation: Certification contests, legitimization, and the survival of organizations in the American automobile industry: 1895-1912.", Strategic Management Journal, Vol 15, pp. 29-44.

Reichheld, F.F. and Sasser, W.E. Jr (1990) "Zero defections: quality comes to services", Harvard Business Review, Vol 68 No 5, pp. 105-11.

Rust, R.T., Ambler, T., Carpenter, G.S., Kumar, V. and Srivastava, R.K. (2004) "Measuring marketing productivity: current knowledge and future directions", Journal of Marketing, Vol 68 No 4, pp. 76-89.

Rust, R.T., Zeithaml, V.A. and Lemon, K.N. (2000) Driving Customer Equity: How Customer Lifetime Value Is Reshaping Corporate Strategy, New York: The Free Press.

Ryals, R. (2002) "Are your customers worth more than money?", Journal of Retailing and Consumer Services, Vol 9 No 5, pp. 241-25

Salminen, R.T. (1999) "Use of references in industrial marketing on three levels of utilization", in Delivering Value out of Bonds, Saren, M. and Tzokas, S. (Eds) Proceedings of the $7^{\text {th }}$ International Colloquium in Relationship Marketing, University of Strathclyde, Scotland, 1999, pp. 172-183.

Salminen, R.T. (2001) "Success factors of a reference visit - a single case study", Journal of Business \& Industrial Marketing, Vol 16 No 6, pp. 487-507.

Salminen, R.T., and Möller, K. (2006) "Role of references in business marketing - towards a normative theory of referencing", Journal of Business-to-Business Marketing, Vol 13 No 1, pp. 1-52.

Sawhney, M. and Zabin, J. (2002) "Managing and measuring relational equity in the network economy", Academy of Marketing Science, Vol 30 No 4, pp. 313-333.

Sirmon, D.G., Hitt, M.A. and Ireland, R.D. (2007) "Managing firm resources in dynamic environments to create value: Looking inside the black box", Academy of Management Review, Vol 32 No 1, pp. 273-292.

Srivastava, R.K., Shervani, T.A. and Fahey, L. (1998) "Market-based assets and shareholder value: A framework for analysis", Journal of Marketing, Vol 62 No 1, pp. 2-18.

Stinchcombe AL. (1965) "Social structure and organizations”, In Handbook of Organizations, March JG (ed). Chicago: Rand McNally: Chicago, pp. 142-193.

Stuart, T.E., Hoang, H. and Hybels, R. (1999) "Interorganizational endorsements and the performance of entrepreneurial ventures", Administrative Science Quarterly, Vol 44 No 2, pp. 315-349.

Veres, Z. (2009) "Competence-based risk perception in the project business", Journal of Business \& Industrial Marketing, Vol 24 No 3/4, pp. 237-244.

Walley, K. Custance, P. Taylor, S., Lindgreen, A. and Hingley, M. (2007) "The importance of brand in the industrial purchase decision: a case study of the UK tractor market", Journal of Business \& Industrial Marketing, Vol 22 No 6, pp. 383-393.

Walter, A., Ritter, T. and Gemünden, H.G. (2001) "Value-creation in buyer-seller relationships: theoretical considerations and empirical results from a supplier's perspective", Industrial Marketing Management, Vol 30 No 4, pp. 365-377.

Walters, D. (1999) "Marketing and operations management: an integrated approach to new ways of delivering value", Management Decision, Vol 37 No 3, pp, 248-258.

Webster, F. E. (1970) "Informal communication in industrial markets", Journal of Marketing Research, Vol 7 No 2, pp. 186-190. 
Wernerfelt, B. (1984) “A resource-based view of the firm”, Strategic Management Journal, Vol 5 No 2, pp. $171-80$.

Westbrook, R. A. (1987) "Product/consumption-based affective responses and postpurchase processes", Journal of Marketing Research, Vol 24 No 3, pp. 258-270.

Windahl, C., Andersson, P., Berggren, C. and Nehler, C. (2004) "Manufacturing firms and integrated solutions: characteristics and implications", European Journal of Innovation Management, Vol 7 No 3, pp. 218- 228.

Yin, R. (1984) Case study research, Sage Publications, Beverly Hills.

Zander, I. and Zander, U. (2005) "The inside track: On the important (but neglected) role of customers in the resource-based view of strategy and firm growth", Journal of Management Studies, Vol 42 No 8, pp. 1519548. 